\title{
A new tribe of fossil digger wasps (Hymenoptera: Crabronidae) from the Upper Cretaceous New Jersey amber and its place in the subfamily Pemphredoninae
}

\section{Новая триба ископаемых роющих ос (Hуmenoptera: Crabronidae) из верхнемелового янтаря Нью-Ажерси и ее положкение в подсемействе Pempredoninae}

\author{
A.V. Antropov \\ A.B. Антропов

\begin{abstract}
Zoological Museum, M.V.Lomonosov Moscow State University, 6 Bol'shaya Nikitskaya str., Moscow 125009, Russia. E-mail: antropov@zmmu.msu.ru

Зоологический музей Московского государственного университета им. М.В.Ломоносова. Большая Никитская ул., 6, Москва
\end{abstract} \\ 125009 , Россия.
}

KEY WORDS: Pemphredoninae, Rasnitsynapini, Palangini, new taxa, New Jersey amber.

КЛЮЧЕВЫЕ СЛОВА: Pemphredoninae, Rasnitsynapini, Palangini, новые таксоны, янтарь Нью-Джерси.

\begin{abstract}
A new tribe of digger wasps, Rasnitsynapini trib.n. (Hymenoptera: Crabronidae, Pemphredoninae), which includes the only known genus and species Rasnitsynapus primigenius gen. et sp.n., is described from the Upper Cretaceous New Jersey amber. The most distinctive characters of the new tribe include complete wing venation, non-elongate first gastral segment without separated sternal petiole, and absence of psammophores, digging tarsal rakes, and pygidial plate. The new tribe occupies a basal position in the phylogenetic tree of the subfamily Pemphredoninae and also represents a sister group to the tribe Spilomenini which is separated from the tribe Pemphredonini. The extinct genus Palanga Budrys is placed within a new tribe, Palangini trib.n. A list of extinct and extant genera of the subfamily Pemphredoninae and a scheme of their probable phylogenetic relationships are pro-
\end{abstract} posed.

РЕЗЮМЕ. Из верхнемелового янтаря НьюДжерси описана новая триба роющих oc Rasnitsynapini trib.n. (Hymenoptera: Crabronidae, Pemphredoninae), включающая один род и вид Rasnitsynapus primigenius gen. et sp.n. Наиболее четкими диагностическими признаками новой трибы являются полное жилкование крыльев, неудлиненный 1-й сегмент брюшка без обособленного стернального стебелька и отсутствие псаммофоров, копательных гребней на лапках и пигидиального поля. Новая триба занимает базальное положение в филогенетическом древе подсемейства Pemphredoninae, а также является сестринской группой трибы Spilomenini, выделенной из состава трибы Pemphredonini. Вымерший род Palanga Budrys помещен в новую три- бy Palangini trib.n. Предложен список современных и ископаемых родов подсемейства Pemphredoninae и схема их вероятных филогенетических отношений.

\section{Introduction}

Four extant tribes containing 55 genera are included into the subfamily Pemphredoninae, which is one of the most generalized taxa of the family Crabronidae (Apoidea). There are 15 fossil genera among them, although 12 genera are cited as having an uncertain position within the subfamily [Pulawski, 2011]. At the same time, the vast majority of extinct genera, including those described from the Cretaceous, is represented by highly specialized forms that make impossible wellgrounded conclusions regarding evolutionary pathways within the subfamily in general.

I have recently completed examination of a fossil pemphredonine wasp from the Upper Cretaceous New Jersey amber. The description of the wasp is given below. The study of this sample allowed for a fresh look at the whole system of Pemphredoninae and to determine relationships of the majority of taxa within the subfamily.

\section{Material and methods}

The specimen was studied under the stereomicroscope Carl Zeiss Stemi SV 6 in a thick sugar solution rather than immersion oil in order to minimize the possibility of damage (strong oblique illumination can somewhat improve visibility of some parts of the fossil body). Digital cameras Canon EOS D40 and Leica 
DFC420 mounted on the stereomicroscope Leica 165 $\mathrm{C}$ have been used to prepare photographs which were subsequently improved when necessary using Adobe Photoshop CS software. Line drawings were prepared using the stereomicroscope Carl Zeiss Stemi SV 6 with a drawing unit and CorelDRAW 7 software. All measurements were made in accordance with the scale bars automatically generated by the Leica DFC420 digital camera.

\section{Identification of the fossil}

Petiolate gaster with sting, simple trochanters, short pronotal collar with straight posterior margin and pronotal lobes which are well-separated from tegulae attribute the studied specimen to Apoidea.

Short pubescence consisting of simple setae, cylindrical hind basitarsomere with cleaning bristles, absence of frontal prominences that cover antennal sockets from above, and middle tibia with a single apical spur attribute it to apoid wasps of the family Crabronidae.

Mandible without ventral notch and lobe, mesopleuron without omaulus or scrobal furrow but with narrow episternal sulcus and weakly developed hypersternaulus, forewing with enlarged pterostigma, apically acute marginal cell that touches wing margin, three submarginal and two discoidal cells attribute the fossil to the subfamily Pemphredoninae.

At the same time, the following character set is also similar to that found in different pemphredonine tribes: parallel inner eye orbits, short clypeus, antennal sockets contiguous to frontoclypeal suture, unmodified ocelli, forewing with complete venation, distinct bent between dorsal and hind faces of propodeum, outlined propodeal dorsal area, absence of psammophores, foretarsal rake, scrobal sulcus, lateral propodeal carinae, separated sternal petiole, and pygidial plate. However, the whole complex of characters does not allow to assign the examined specimen to any tribe of the subfamily Pemphredoniae. Consequently, it is placed within the separate tribe, Rasnitsynapini trib.n. of the Pemphredoninae.

\section{Taxonomy}

Order Hymenoptera Linnaeus, 1758

Superfamily Apoidea Latreille, 1802

Family Crabronidae Latreille, 1802

Subfamily Pemphredoninae Dahlbom, 1835

Tribe Rasnitsynapini Antropov, trib.n.

Type genus - Rasnitsynapus gen.n. (stem: Rasnitsynap-).

\section{Diagnosis of the tribe}

1. Eyes bare; inner eye orbits almost parallel; ocelli unmodified, in an obtuse triangle.

2. Antennal sockets contiguous to frontoclypeal su- ture; antenna unmodified, with 12 segments.

3. Clypeus transverse, very short; labrum short, not projecting beyond anterior margin of clypeus.

4. Mandible without ventral notch or angle.

5. Pronotal collar lower than scutum, with moderately convex lateral angles and without distinct transverse carina (Figs 3, 6); lateral lobe of pronotum separated from tegula.

6. Admedial lines weak, reaching $1 / 3$ scutal length; parapsidal lines not developed; adlateral lines longer than half of scutum; transverse postscutal furrow deep, smooth; scutellum without posterolateral lobes; postscutellum transverse, short (Fig. 5).

7. Episternal sulcus developed, not areolate; hypersternaulus short, not reaching 1/3 mesopleural length, not areolate; scrobal sulcus, omaulus, sternaulus, and postspiracular and acetabular carinae not developed.

8. Hind femur not truncate apically; mid tibia with a single apical spur almost reaching 1/3 tibial length; tarsomeres unmodified; claws simple; arolii developed; foretarsal rake absent.

9. Forewing (Figs 5, 8) with complete venation, including distinctly enlarged pterostigma, and closed long marginal cell with acute apex touching wing margin; three submarginal, two discoidal, and two subdiscoidal cells; $c u$ - $a$ antefurcal.

10. Hindwing with two closed cells (Figs 3, 6, 8) and five hamuli; vein $R S$ straight and shortened although anteriorly directed to wing base; $c u$ - $a$ postfurcal; jugal lobe invisible.

11. Propodeum (Figs 3, 6) not elongate, with distinct bent between dorsal and hind faces; dorsal and hind faces of almost equal length; hind face with oval medial pit; lateral carinae or areolate lines absent on propodeum; dorsal area of propodeum distinctly outlined laterally with areolate lines, semi-oval, reaching posterior margin of dorsal face.

12. Gaster without separated sternal petiole (Fig. 6); segment I not longer its width; sternites convex; pygidial plate absent.

\section{Comparison with tribes of the subfamily Pem- phredoninae}

Members of the three pemphredonine tribes. i.e. Entomosericini, Odontosphecini, and Psenini, have complete forewing venation.

The tribes Entomosericini, Odontosphecini, and Psenini differ from Rasnitsynapini trib.n. by having antennal sockets not contiguous to more or less elongate clypeus, by moderately enlarged pterostigma, and by presence of pygidial plate.

The tribes Entomosericini and Odontosphecini differ from Rasnitsynapini trib.n. by having non-parallel inner eye orbits (convergent below in Entomosericini or above in Odontosphecini), broad and distinctly anteriorly narrowed submarginal cell III reaching apex of marginal cell (Odontosphecini) or projecting apex of the cell (Entomosericini), having both recurrent veins that end at submarginal cell II, discoidal cell I being 

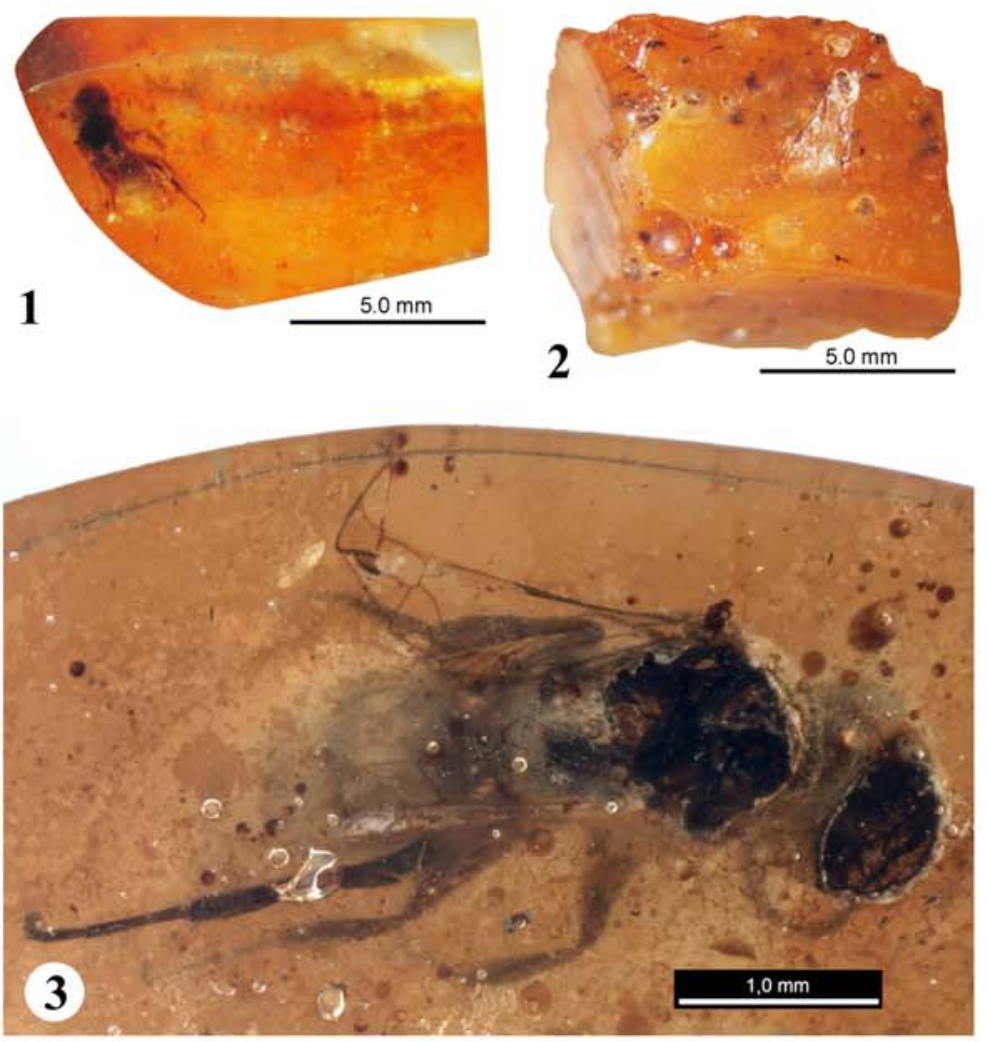

Figs 1-5. Photos of the general view of the sample and fragments of Rasnitsynapus primigenius Antropov, gen. et sp.n. (Holotype, no. NJ-6999.). 1 - sample of amber with the body, total (dorsal view); 2 - sample of amber with scutum, scutellum, postscutellum, and right forewing, total (ventral view); 3 - body, specimen at high magnification, dorsal view; 4 - body, specimen at high magnification, lateral view; 5 - scutum, scutellum, postscutellum, and right forewing at high magnification, ventral view.

Рис. 1-5. Фотографии общего вида образца и фрагментов Rasnitsynapus primigenius Antropov, gen. et sp.n. (Голотип, 웅 no. NJ-6999). 1 - образец янтаря с телом, общий вид сверху; 2 - образец янтаря со среднеспинкой, щитиком, заднещитиком и правым передним крылом, общий вид снизу; 3 - тело, экземпляр при большом увеличении, вид сверху; 4 - тело, экземпляр при большом увеличении, вид сбоку; 5 среднеспинка, щитик, заднещитик и правое переднее крыло при большом увеличении, вид снизу.
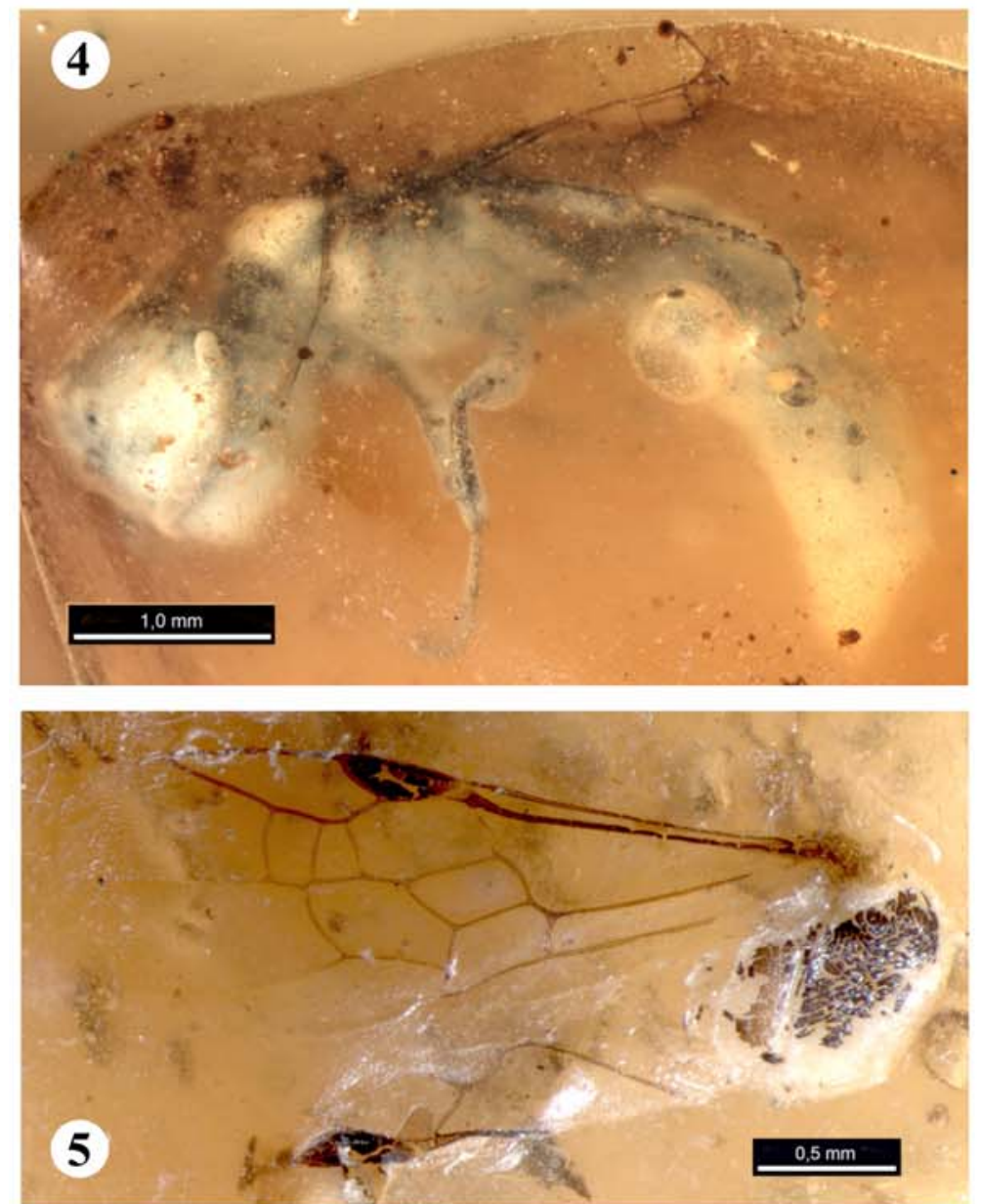
longer than submarginal cell I, not shortened hindwing vein $R S$, presence of foretarsal rake, and apically truncate hind femur.

The tribe Entomosericini differs from Rasnitsynapini trib.n. by having relatively shorter forewing marginal cell, very long midtibial apical spur, strong toothlike hindtibial spines, and by presence of preapical depressions on gastral tergites.

The tribe Odontosphecini differs from Rasnitsynapini trib.n. by having vestigial lateral ocelli that are close to mid ocellus, relatively short marginal cell of forewing that is narrowly truncate at apex, and by absence of episternal sulcus.

The tribes Psenini and Pemphredonini differ from Rasnitsynapini trib.n. by having distinct petiole formed by gastral sternite I. Furthermore, the tribe Psenini differs from Rasnitsynapini trib.n. by antennal sockets not contiguous to frontoclypeal suture and the tribe Pemphredonini - by having more or less modified mandibles and reduced wing venation.

\section{Rasnitsynapus Antropov, gen.n.}

TYPE SPECIES: Rasnitsynapus primigenius sp.n.; by monotypy and present designation.

ETYMOLOGY. Genus name is masculine. It is named after the leading Russian expert on fossil insects, Prof. A.P. Rasnitsyn, and consists of his surname and initials.

DIAGNOSIS OF THE GENUS. The same as for the tribe.

COMPARISON WITH THE GENERA OF THE SUBFAMILY PEMPHREDONINAE. Only two extinct pempredonine genera having complete wing venation. i.e. Eomimesa Budrys, 1993 and Palanga Budrys, 1993, are known from the Eocene Baltic amber. Both genera differ from Rasnitsynapus gen.n. by having elongate clypeus, presence of scrobal sulcus, propodeum without distinct bent between dorsal and hind faces, and presence of pygidial plate.

Eomimesa differs from Rasnitsynapus gen.n. by having transversely carinate pronotal collar, absence of hypersternaulus, presence of foretarsal rake, not enlarged pterostigma, both recurrent veins ending on submarginal cell II, and submarginal cell III and discoidal cell II significantly widened basally, long gastral petiole consisting of only sternite I, and small but distinct pygidial plate. The genus Eomimesa is therefore certainly related to the tribe Psenini [Budrys, 1993].

Palanga is similar to Rasnitsynapus gen.n. by having antennal sockets contiguous to frontoclypeal suture, absence of foretarsal rake, presence of hypersternaulus, recurrent veins I and II ending on submarginal cells I and III respectively, postfurcal hindwing $c u-a$, and absence of separated sternal petiole. At the same time, Palanga differs from Rasnitsynapus gen.n. by having elongate clypeus, weakly developed vertex and temples, uniformly rounded and ecarinate pronotal collar without lateral angles, more weakly enlarged pterostigma, submarginal cell III and discoidal cell II significantly widened posteriorly, longer vein $R S$, six hamuli, relatively longer gastral segment $\mathrm{I}$, and small but distinct pygidial plate.

The monotypic Nearctic Ammopsen Krombein, 1959 that is perhaps the most generalized genus of the tribe Psenini [Bohart, Menke, 1976] is the most similar to Rasnitsynapus gen.n. among all extant genera of Pemphredoninae with complete wing venation by having recurrent veins I and II ending on submarginal cells I and III respectively and also by having somewhat shortened hindwing vein $R S$ and postfurcal $\mathrm{cu}-a$. Ammopsen differs from Rasnitsynapus gen.n. by having not enlarged pterostigma, nearly square submarginal cell III reaching distal third of marginal cell, recurrent vein I ending near end of submarginal cell I, discoidal cell I longer than submarginal cell I, and forewing media diverging at a distance less than $c u$ - $a$. Furthermore, Ammopsen differs by having developed scrobal sulcus, foretarsal rake, sternal petiole, and broad triangular pygidial plate.

\section{Rasnitsynapus primigenius Antropov, sp.n. Figs 1-8.}

ETYMOLOGY. After primigenius, the Latin masculine adjective, meaning "primary" and "initial".

MATERIAL. Holotype + , no. NJ-6999. New Jersey amber: Middlesex Co., Sayreville, White Oaks Pit. Paul Nascimbene coll., 1995. Late Cretaceous. The sample is represented by two amber pieces: the piece containing the main part of the specimen with damaged dorsum of thorax and right forewing is $11.9 \times 7.7 \times 5.0 \mathrm{~mm}$ with dorsal side covered with translucent plastic (Fig. 1); the counterpart is $10.6 \times 7.2 \times 6.3 \mathrm{~mm}$ and contains scutum, scutellum, postscutellum, complete right forewing, and a part of left forewing (Fig. 2). Holotype is deposited in the collection of the American Museum of Natural History (New York, NY, USA).

DESCRIPTION. Female. Head (Figs 4, 7) thickened; frontal carinae absent; genae very short; ocelli in very obtuse triangle; occipital carina thin, visible at least dorsally and laterally (invisible ventrally); inner eye orbits almost parallel; clypeus very short, apically broadly rounded; antennal sockets touching frontoclypeal suture; scape short, rounded; antennal articles scarcely longer their maximum thickness; mandibles almost completely hidden under clypeus (tips invisible from outside); palpi short, palpal formula unknown. Scutum (Figs 4, 7) uniformly convex, somewhat higher than pronotal collar; scutellum (Fig. 5) convex to almost flat, somewhat narrowed posteriorly and wider than long; postscutellum short, transverse; mesopleuron uniformly convex laterally; precoxal tubercle absent. Structure of coxae cannot be seen; femora uniformly thickened prebasally (Figs 3, 4, 6, 7), unmodified; mid tibia with sparse short setae; hind tibia similarly setose and with sparse short external spines; arolium not shorter than claws. Forewing (Fig. 8) with apically acute marginal cell (r), touching wing margin; submarginal cell I (1rm) considerably larger than discoidal cell I (1mcu); submarginal cell II $(2 \mathrm{rm})$ is the narrowest, widened posteriorly $(2 M>3 R S)$; submar- 


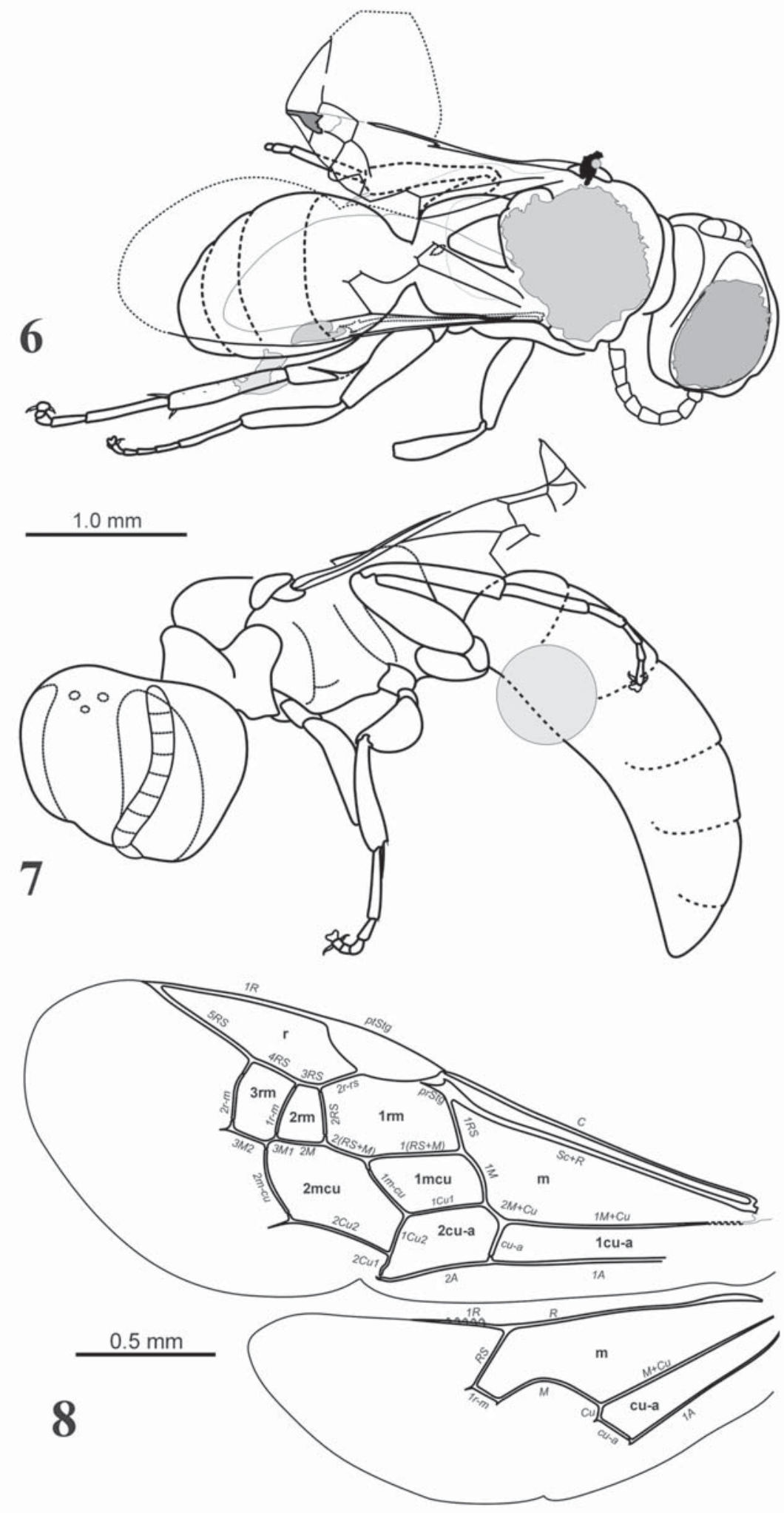

Figs 6-8. Line drawings of the 9 holotype of Rasnitsynapus primigenius Antropov, gen. et sp.n. 6 - body, drawing, dorsal view; 7 body, drawing, lateral view; 8 - wing venation.

Рис. 6-8. Рисунки голотипа Rasnitsynapus primigenius Antropov, gen. et sp.n., + , no. NJ-6999. 6 — тело, вид сверху; 7 — тело, вид сбоку; 8 - жилкование крыльев. 
ginal cell III wider than II, widened anteriorly $(4 R S>$ $3 M 2)$; recurrent vein I ( $1 m-c u)$ ending on submargnal cell I at a larger distance than base of submarginal cell II $[2(R S+M)>2 M]$; recurrent vein II $(2 m-c u)$ ending on submarginal cell III near its proximal angle; $c u-a$ antefurcal, longer than $2 M+C u$, joining vein $1 M+C u$ at an obtuse angle. Hindwing with vein $R S$ twice longer than $r-m$ and almost twice longer than $c u-a$, straight, joining vein $R$ at an obtuse angle; $c u$ - $a$ postfurcal; vein $1 R$ with an undivided row of 5 hamuli; jugal lobe cannot be seen. Propodeum without lateral carinae (Figs $3,6)$; dorsal area triangular, distinctly outlined laterally by furrow and reaching bent between dorsal and hind faces. Gastral terga without lateral ridges and transverse basal constrictions.

Measurements, mm. Length of head, 0.9; thorax, 1.0; propodeum, 0.65; gaster, 2.7; forewing, 2.8; hindwing, 1.9 ; tibiae: fore, 0.71 ; mid, 0.67 ; hind 0.94 ; femora: fore, 0.62 ; mid, 0.63 ; hind 0.81 .

Minimum distance between ends of veins: forewing: $C, 1.2 ; S c+R, 1.16$; prStg, 0.05; ptStg, 0.44; $1 R$, $0.66 ; 1 R S, 0.2 ; 2 R S, 0.2 ; 3 R S, 0.08 ; 4 R S, 0.18 ; 5 R S$, $0.46 ; 2 r-r s, 0.16 ; 1 M, 0.21 ; 2 M, 0.18 ; 3 M 1,0.04 ; 3 M 2$, $0.13 ; 1 r-m, 0.22 ; 2 r-m, 0.26 ; 1(R S+M), 0.35 ; 2(R S+M)$, $0.16 ; 1 m-c u, 0.25 ; 2 m-c u, 0.29 ; 1 M+C u, 0.91 ; 2 M+C u$, $0.09 ; 1 C u 1,0.28 ; 1 C u 2,0.16 ; c u-a, 0.15 ; 2 C u 2,0.37$; $2 A, 0.4 ; 2 C u 1,0.08$; hindwing: $1 R, 0.36 ; R S, 0.23 ; 1 r-$ $m, 0.1 ; M, 0.37 ; C u, 0.05 ; c u-a, 0.14$.

A significant part of the body is covered with milky coating, hiding the sculpture of surface and its pubescence; the latter is obviously very short. Apical tergite and preapical areas of gastral sternites without bristles. Scutum densely and uniformly punctate; propodeal dorsum minutely and densely cellulate and mat laterad of triangular area.

\section{Biology}

Although reliable data on biology of Rasnitsynapus gen.n. are absent, analysis of some structural features of the female allows to make certain conclusions about its nesting sites. For example, absence of any adaptations for digging (clypeal projections, digging foretarsal rake, psammophores on mandibles, temples, fore trochanters and femora, flat sculptured and/or more or less densely setose pygidial plate) indicates that females were not able to dig nests in the ground as well as gnaw out nesting cavities in the wood. They almost certainly were xylobionts who used pre-existing cavities like many other pemphredonines. We can therefore strongly suppose multiple independent transitions to making ground nests in the subfamily Pemphredoninae, whereas the xylobiotic way of life was the primary one.

\section{Discussion}

Up to now, digger wasps of the subfamily Pemphredoninae were divided into four tribes [Pulawski,
2011]. Two of them, Entomosericini (three species of the genus Entomosericus Dahlbom, 1845 in the Palaearctic Region) and Odontosphecini (five species of the genus Odontosphex Arnold, 1951 in the Ethiopian and Neotropical Regions) represent relict groups. Representatives of the both tribes have complete wing venation, entire gastral tergite I, and developed pygidial plate in females.

Certain unique features, which are not found in other Pemphredoninae, characterize both tribes, for example, expanded and apically truncate hind femora. In addition, in Entomosericus inner eye orbits converge below, and parameres are apically bilobed, whereas in Odontosphex inner eye orbits converge above, and lateral ocelli are distinctly modified. In addition, scrobal suture is developed in Entomosericus, but absent in Odontosphex. I believe that relationships of these tribes with other pemphredonines, as well as their phylogenetic position within the subfamily, are somewhat unclear.

The remaining pemphredonines, excluding the genera Palanga and Rasnitsynapus gen.n., form a more compact group, which, in turn, can be clearly subdivided mostly by the structure of gastral tergite I.

The tribe Psenini and the subtribes Pemphredonina and Stigmina differ by having acrotergite I and the distal part of gastral tergite I separated, and, accordingly, always developed and separate sternal petiole. Furthermore, location of antennal sockets far above the frontoclypeal suture and preservation of the complete wing venation are characteristic of the tribe Psenini.

On the contrary, antennal sockets contiguous to the frontoclypeal suture and more or less reduced forewing venation are characteristic of the subtribes Pemphredonina and Stigmina.

It should also be noted that reduction of wing venation in these subtribes is associated with merging of submarginal cells I and II because of reduction of vein $2 R S$ (atavistic traces of this vein can be seen in the extinct genus Iwestia Rasnitsyn et Jarzembowski, 1998 and sometimes appear in extant species, for example, in Pemphredon Latreille, 1796 with widened distal submarginal cell).

The second trend of reduction of wing venation in the subtribe Pemphredonini known only among extinct genera is a progressive reduction of the recurrent vein II. This vein is translucent and weakly developed in Rovnoecus Antropov, 2009, and completely reduced in Eopinoecus Budrys, 1993. Another fossil with reduced recurrent vein II is Palarpactophilus Ohl et Bennett, 2009, which was presumably assigned to the subtribe Spilomenina in the original description. However, features like complete occipital carina, 6-segmented maxillary palpus, weakly enlarged pterostigma, proximally elongate submarginal cell formed by merged SM1 and SM2, areolate episternal sulcus and hypersternaulus, and, most of all, sternal petiole of gaster are not characteristic of Spilomenina, but indicate that Palarpactophilus should be attributed to Pemphredonina (in the 
sense accepted here). Palarpactophilus is most closely related to Eopinoecus, forming together with the latter genus a pair of sister taxa, which are separated by a distinct synapomorphy, i.e. a complete reduction of the recurrent vein II and therefore of the discoidal cell II. In turn, the most apparent autapomorphy of Palarpactophilus is a proximally bent posterior veinlet $(M)$ of the medial vein of the forewing, and that of Eopinoecus is an obviously shortened cubital cell (cu-a) of the hindwing.

Consequently, I include only two subtribes, i.e. Pemphredonina and Stigmina, into the tribe Pemphredonini.

In turn, the subtribes Spilomenina and Ammoplanina are characterized by the undivided gastral tergite I and an even greater degree of reduction of wing venation, which occurred via different pathways. First of all, I believe that an evolutionary reversion in the structure of gastral tergite I, which implies separation of acrotergite I from sternite I that is fused with the acrotergite, as well as secondary fusion of acrotergite I with the distal part of tergite I, is almost impossible. Accordingly, undivided gastral tergite I of Spilomenina and Ammoplanina should be considered as the initial (plesiomorphic) state, and reduction of their forewing venation, primarily by disappearance of submarginal cell III - as one of the synapomorphies of those two subtribes. I consider the subtribes Spilomenina and Ammoplanina as sister groups within a separate tribe Spilomenini that stemmed off other pemphredonines at least in the Lower Cretaceous. Further divergence of the Spilomenina and Ammoplanina is likely to be explained by their evolution in habitats with different physical conditions, i.e. forests for Spilomenina and arid sites for Ammoplanina respectively [Antropov, 2009].

Two Cretaceous genera, Lisponema Evans, 1969 and Psolimena Antropov, 2000, occupy a special position within the subtribe Spilomenina, because they differ by the narrowly truncate apex of marginal cell that ends at a distance from the anterior margin of the wing. I consider these cases as dead ends of further reduction of the wing venation, similar to those independently occurring, for example, in miniaturized meliponine bees (Apidae, Apinae, Apini, Meliponina) [Michener, 2000]. Those character states are not found among extant members of Spilomenina, and apex of marginal cell in those insects always touches the wing margin, even in the case of reduction of the anterior vein $1 R$ in Xysma Pate, 1937.

The genera Palanga and Rasnitsynapus gen.n. do not fit the scheme described above. The complete wing venation and an entire gastral tergite I are characteristic of both genera. However, significant differences do not allow to place them into the same tribe.

Palanga has elongate clypeus, developed scrobal suture, areolate hypersternaulus, scarcely enlarged pterostigma, propodeum without a distinct bent between its dorsal and hind faces, longer gastral segment I, and a pygidial plate on the last gastral tergite. Fur- thermore, wing venation of Palanga follows the generalized pattern without an obvious trend to costalization. Consequently, I believe that the genus Palanga should be placed within a separate tribe Palangini trib.n.

Tribe Palangini Antropov, trib.n.

Type genus - Palanga Budrys, 1993; by present designation.

\section{Diagnosis of the tribe}

1. Eyes bare; inner eye orbits almost parallel; ocelli unmodified, in rectangular triangle.

2. Antennal sockets contiguous to frontoclypeal suture; antenna unmodified, with 12 segments.

3. Clypeus elongate, weakly bilobed apically; labrum short, scarcely projecting beyond anterior margin of clypeus.

4. Occipital carina complete, circular, reaching midventral line of head.

5. Mandible bidentate, with acute inner lobe, without ventral notch or angle; palpal formula 6-4.

6. Pronotal collar lower than scutum, with moderately convex lateral angles and without distinct transverse carina; lateral lobe of pronotum separated from tegula.

7. Admedial lines distinct; parapsidal lines not developed; adlateral lines longer than half scutum; transverse postscutal furrow deep, smooth; scutellum without posterolateral lobes; postscutellum transverse, short (Fig. 5).

8. Episternal sulcus developed, areolate; scrobal sulcus distinct, smooth; episcrobal area smooth, strongly convex; hypersternaulus reaching 1/3 mesopleural length, areolate; omaulus, sternaulus, and postspiracular and acetabular carinae absent.

9. Hind femur not truncate apically; mid tibia with a short single apical spur; tarsomeres unmodified; foretarsal rake absent; claws simple; arolii developed.

10. Forewing with complete venation, including scarcely enlarged pterostigma, and closed long marginal cell with acute apex touching wing margin; three submarginal, two discoidal, and two subdiscoidal cells; $c u-a$ antefurcal.

11. Hindwing with two closed cells and six hamuli; vein $R S$ not shortened, anteriorly directed to wing base; $c u$ - $a$ postfurcal; jugal lobe invisible.

12. Propodeum not elongate, without distinct bent between dorsal and hind faces; lateral carinae or areolate lines of propodeum absent; dorsal area of propodeum not outlined.

13. Gaster without separated sternal petiole; segment I longer its width; sternites convex; pygidial plate present, short and narrow, weakly outlined laterally.

\section{Genus Palanga Budrys, 1993}

TYPE SPECIES: Palanga succinea Budrys, 1993; by monotypy and original designation. 
Table 1. List of taxa of the subfamily Pemphredoninae (including extinct and extant genera). Таблица 1. Список таксонов подсемейства Pemphredoninae (включая вымершие и современные роды).

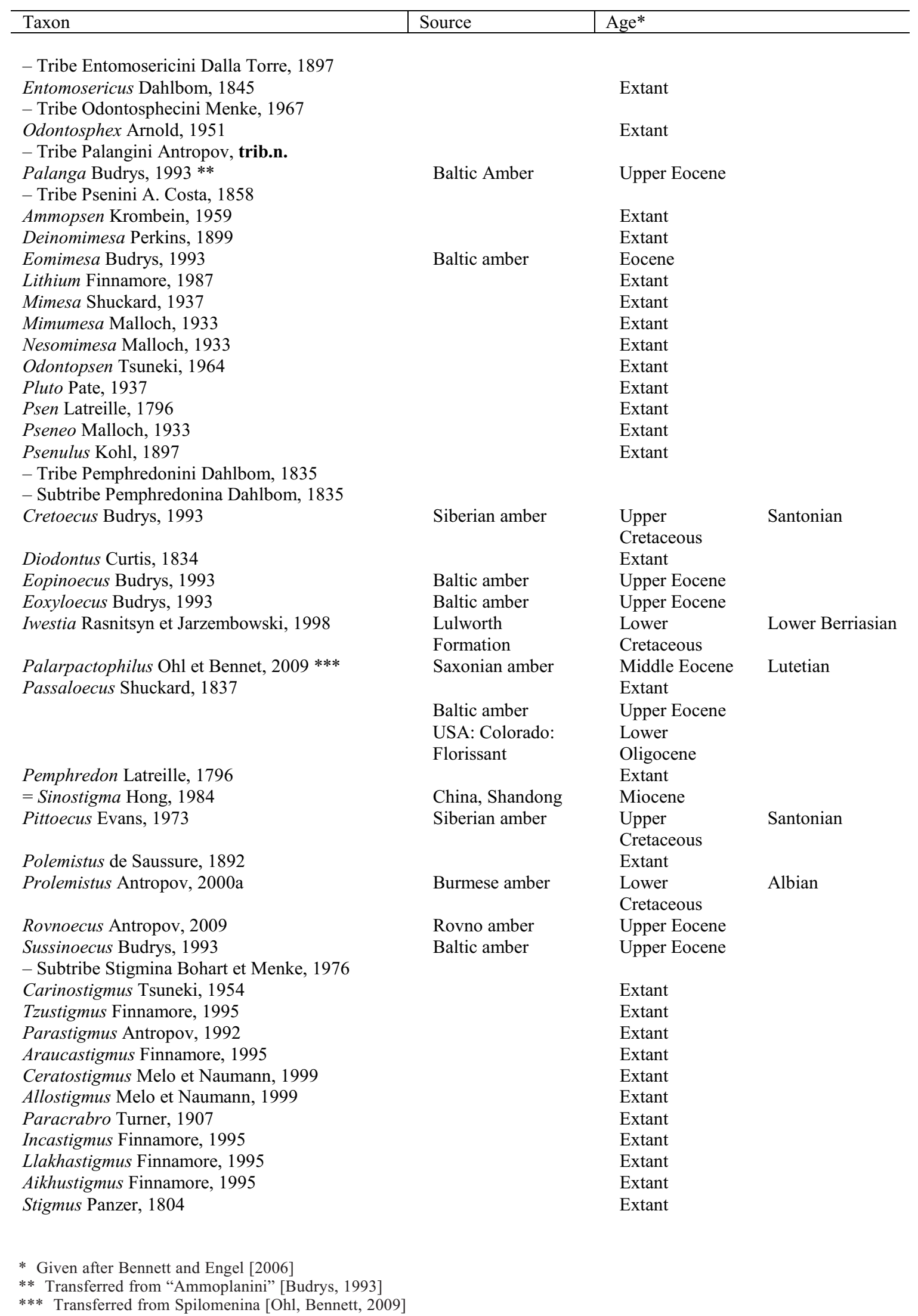


Table 1 (continued). Таблица 1 (продолжение).

\begin{tabular}{|c|c|c|c|}
\hline Taxon & Source & Age* & \\
\hline $\begin{array}{l}\text { - Tribe Rasnitsynapini Antropov, trib.n. } \\
\text { Rasnitsynapus Antropov. gen.n. }\end{array}$ & New Jersey amber & $\begin{array}{l}\text { Upper } \\
\text { Cretaceous }\end{array}$ & Turonian \\
\hline $\begin{array}{l}\text { - Tribe Spilomenini Menke, } 1989 \\
\text { - Subtribe Spilomenina Menke, } 1989\end{array}$ & & & \\
\hline Arpactophilus F. Smith, 1863 & & Extant & \\
\hline Cretospilomena Antropov, 2000a & Burmese amber & $\begin{array}{l}\text { Lower } \\
\text { Cretaceous }\end{array}$ & Albian \\
\hline Lisponema Evans, 1969 & Canadian amber & $\begin{array}{l}\text { Upper } \\
\text { Cretaceous }\end{array}$ & Campanian \\
\hline Microstigmus Ducke, 1907 & & Extant & \\
\hline Psolimena Antropov, 2000b & New Jersey amber & $\begin{array}{l}\text { Upper } \\
\text { Cretaceous }\end{array}$ & Turonian \\
\hline Spilomena Shuckard, 1838 & & Extant & \\
\hline $\begin{array}{l}\text { Xysma Pate, } 1937 \\
\text { - Subtribe Ammoplanina Evans, } 1959\end{array}$ & & Extant & \\
\hline Ammoplanellus Gussakovskij, 1931 & & Extant & \\
\hline Ammoplanops Gussakovskij, 1931 & & Extant & \\
\hline Ammoplanus Giraud, 1869 & & Extant & \\
\hline Ammostigmus Antropov, 2010 & & Extant & \\
\hline Parammoplanus Pate, 1939 & & Extant & \\
\hline Protostigmus Turner, 1918 & & Extant & \\
\hline Pulverro Pate, 1937 & & Extant & \\
\hline Timberlakena Pate, 1939 & & Extant & \\
\hline
\end{tabular}

REMARKS. Budrys (1993) suggested that Palan$g a$ is related to extant genera Arpactophilus F. Smith, 1863 and Spilomena Shuckard, 1838 because of the similar palpal formula (5-4) but differs in complete forewing venation. Subsequent studies have shown that it really had 6-segmented maxillary palpi. I believe that the tribe Palangini trib.n. should be considered the basal group of the Pemphredoninae. At the same time, it is obviously related to the tribes having the detached sternal petiole but not the initial structure of gastral segment I. However, we cannot consider the tribe $\mathrm{Pa}-$ langini trib.n. as an ancestral taxon for the above mentioned groups, because the sternal petiole appeared much earlier in the course of evolution. I suggest that Palangini trib.n. should be considered as a sister group to Psenini and Pemphredonini (in the sense accepted here), and all those groups are derived from a more generalized ancestral taxon.

Rasnitsynapus gen.n. has a very short clypeus, its scrobal suture absent, hypersternaulus looking like a weak and short furrow, pterostigma strongly enlarged, propodeum with a distinct bent between the dorsal and hind faces, gastral segment I short, and pygidial plate absent. Venation of both fore and hind wings of Rasnitsynapus gen.n. demonstrates a clear trend to costalization, which is expressed by a significant narrowing of submarginal cells II and III, as well as by abbreviation of vein $R S$ of the hindwing. Accordingly, the tribe Rasnitsynapini trib.n. should be considered as a sister group to the tribe Spilomenini.
These conclusions are summarized in the table of the taxa given below (Table 1) and the scheme of the most probable phylogenetic relationships between the genera within the subfamily Pemphredoninae (Fig. 9). These table and scheme are based on certain reviews and similar publications [Bohart, Menke, 1976; Menke, Fernández, 1996; Menke, 1997b; de Melo, 1999; Pulawski, 2011], while necessary changes are made on the basis of the original research [Antropov, 2000a,b, 2009, 2010; Antropov, Perkovsky, 2009] and publications on extant and extinct members of the subfamily Pemphredoninae [Cockerell, 1906; Evans, 1969, 1973; Marshakov, 1976, 1979; Budrys, 1993; Finnamore, 1995; Menke, 1997a, 1989; Rasnitsyn et al., 1998; Bouček, 2001; Matthews, Naumann, 2002; Smith, 1983, 2009, 2010; Ohl, Bennett, 2009].

A KEY FOR DISTINGUISHING BETWEEN TRIBES OF THE SUBFAMILY PEMPHREDONINAE THAT ARE RECOGNIZED BY THE AUTHOR (THE MAIN APOMORPHIES THAT DIFFERENTIATE THE TRIBES ARE GIVEN IN BOLD).

1. Gastral tergite I complete, without a separate acrotergite

- Gastral tergite I with a separate acrotergite and petiole

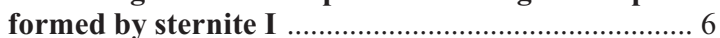

2. Inner eye orbits non-parallel; clypeus more or less elongate; antennal sockets not contiguous to frontoclypeal

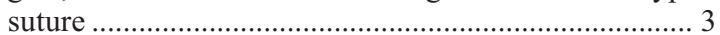

- Inner eye orbits parallel; antennal sockets contiguous to frontoclypeal suture . 


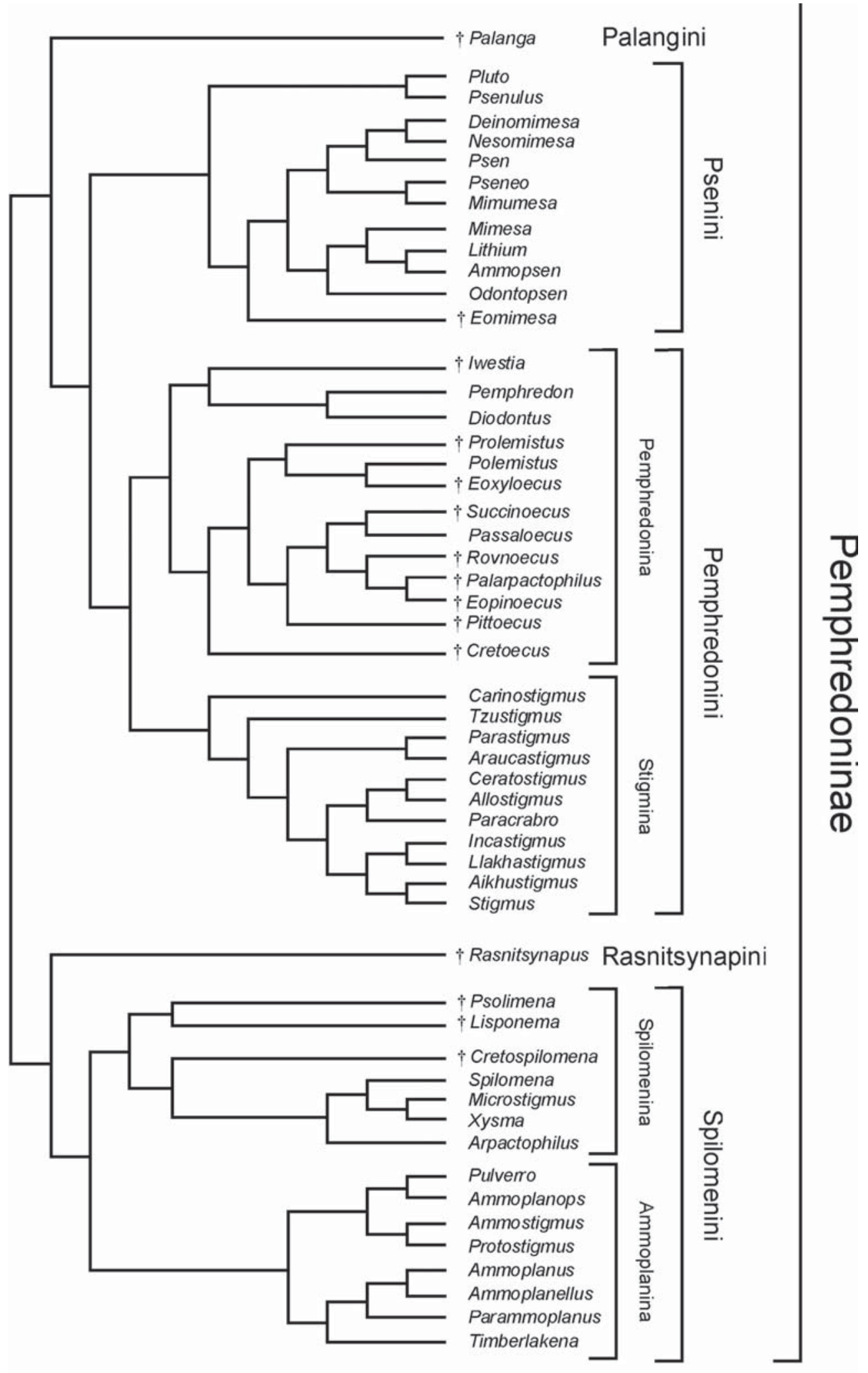

Fig. 9. Hypothetical scheme of phylogenetic relationships of supraspecific taxa of the subfamily Pemphredoninae (tribes Entomosericini and Odontosphecini are not included; extinct genera are marked with $\dagger$ ).

Рис. 9. Предположительная схема филогенетических отношений надвидовых таксонов в подсемействе Pemphredoninae (трибы Entomosericini и Odontosphecini не включены; ископаемые роды отмечены знаком †). 
3. Inner eye orbits converging below; lateral ocelli not modified; marginal cell of forewing acute apically; episternal sulcus present; midtibial apical spur very long; hindtibial spines strong, tooth-like; gastral tergites with preapical depressions .......... tribe Entomosericini

- Inner eye orbits converging above; lateral ocelli vestigial and close to mid ocellus; marginal cell of forewing narrowly truncate apically; episternal sulcus absent; midtibial apical spur of moderate length; hindtibial spines simple; gastral tergites without preapical depressions tribe Odontosphecini

4. Clypeus elongate; pterostigma scarcely enlarged; scrobal suture present; hypersternaulus areolate; gastral segment I elongate; pygidial plate present tribe Palangini trib.n. $\dagger$

- Clypeus short; pterostigma strongly enlarged; scrobal suture absent; hypersternaulus weak, not areolate; gastral segment I not elongate; pygidial plate absent or present

5. Forewing with more or less reduced venation (not more than two submarginal cells and one discoidal cell present); submarginal cell II not narrowed

tribe Spilomenini

5a. Forewing with marginal cell shorter than pterostigma (marginal cell open apically in some genera)

subtribe Ammoplanina

5b. Forewing with marginal cell longer than pterostigma (apex of marginal cell always acute and touching wing margin) . subtribe Spilomenina

- Forewing with complete venation (with three submarginal and two discoidal cells); submarginal cells II and III distinctly narrowed ....... tribe Rasnitsynapini trib.n. $\dagger$

6. Forewing venation reduced (with only two submarginal cells, first of them formed by merged submarginal cells I and II); antennal sockets contiguous to short clypeus; hypersternaulus areolate; pygidial plate absent or present tribe Pemphredonini

6a. Forewing with moderately to non-enlarged pterostigma and usually with two recurrent veins (if recurrent vein II scarcely visible or reduced, then hypersternaulus areolate) subtribe Pemphredonina

$6 \mathrm{~b}$. Forewing with strongly enlarged pterostigma and without recurrent vein; hypersternaulus not areolate subtribe Stigmina

- Forewing venation complete (three submarginal cells present); antennal sockets not contiguous to more or less elongate clypeus; hypersternaulus absent; pygidial plate present tribe Psenini

\section{ACKNOWLEDGEMENTS}

I am very grateful to Dr. David Grimaldi for opportunity to study the specimen and to Mr. V.A. Kolyada for his help with taking high magnification microphotographs.

\section{References}

Antropov A.V. 2000a. A new digger wasp (Hymenoptera, Sphecidae, Pemphredoninae) from New Jersey amber // Grimaldi D. (ed.). Studies on fossils in amber, with particular reference to the Cretaceous of New Jersey. Leiden: Back. P.339-343.

Antropov A.V. 2000b. Digger wasps (Hymenoptera, Sphecidae) in Burmese amber // Bulletin of the Natural History Museum. Geology Series. Vol.56. No.1. P.59-77.
Antropov A.V. 2009. [Body size diminution and the ways of evolution of wing venation in aculeate hymenopterous insects (Insecta: Hymenoptera: Aculeata: Apoidea). An attempt of functional interpretation] // Sviridov A.V., Shatalkin A.I. (eds.). Evolution and systematics: Lamarck and Darwin in modern studies. Archives of the Zoological Museum of Moscow State University. Vol.50. P.247-274 [in Russian].

Antropov A.V. 2010. [Ammostigmus, a new genus of digger wasps of the subtribe Ammoplanina (Hymenoptera, Crabronidae) from southwestern India] // Zoologichesky Zhurnal. Vol.89. No.4. P.459-465 [in Russian].

Antropov A.V., Perkovsky E.E. 2009. Rovnoecus, a new genus of digger wasps (Hymenoptera, Crabronidae, Pemphredoninae) from the Rovno amber // Paleontological Journal. Vol.43. P.1019-1023.

Bennett D.J., Engel M.S. 2006. A new moustache wasp in Dominican amber, with an account of apoid wasp evolution emphasizing Crabroninae (Hymenoptera: Crabronidae) // American Museum Novitates. Vol.3529. P.1-10.

Bohart R.M., Menke A.S. 1976. Sphecid Wasps of the World. A generic revision. Berkeley, Los Angeles, London: University of California Press. 695 pp.

Bouček Z. 2001. Palaearctic species of Ammoplanus (Hymenoptera: Sphecidae) // Journal of Natural History. Vol.35. P.849-929.

Budrys E.R. 1993. Digger wasps of the subfamily Pemphredoninae (Hymenoptera, Sphecidae) from the Baltic and Taimyr amber // Acta Entomologica Lituanica. Vol.11. P.34-56.

Cockerell T.D.A. 1906. Fossil Hymenoptera from Florissant, Colorado // Bulletin of the Museum of Comparative Zoology. Vol.50. No.2. P.33-58.

de Melo G.A.R. 1999. Phylogenetic relationships and classification of the major lineages of Apoidea (Hymenoptera), with emphasis on the crabronid wasps // Scientific Papers. Natural History Museum. The University of Kansas. Vol.14. P.1-55.

Evans H.E. 1969. Three new Cretaceous aculeate wasps (Hymenoptera) // Psyche. Vol.76. No.3. P.251-261.

Evans H.E. 1973. Cretaceous aculeate wasps from Taimyr, Siberia (Hymenoptera) // Psyche. Vol.80. No.3. P.166-178.

Finnamore A.T. 1995. Revision of the world genera of the subtribe Stigmina (Hymenoptera: Apoidea: Sphecidae: Pemphredoninae). Part $1 / /$ Journal of Hymenoptera Research. Vol.4. P.204-284.

Marshakov V.G. 1976. [Digger wasps of the genera Eremiasphecium Kohl, Ammoplanus Gir., Ammoplanops Guss. and Anomiopteryx Guss. (Hymenoptera, Sphecidae) of the fauna of the USSR and Mongolia]// Entomologicheskoe Obozrenie. Vol.55. No.3. P.668-682 [in Russian].

Marshakov V.G. 1979. [Fossorial wasps of the genera Protostigmus Turner and Ammoplanus Giraud (Hymenoptera, Sphecidae) from Mongolia and Middle Asia] // Nasekomye Mongolii. Vol.6. P.362-374 [in Russian].

Matthews R.W., Naumann I.D. 2002. Description and biology of nine new species of Arpactophilus (Hymenoptera: Crabronidae), with a key to described Australian species // Journal of Hymenoptera Research. Vol.11. No.1. P.101-133.

Menke A.S. 1989. Arpactophilus reassessed, with three bizarre new species from New Guinea (Hymenoptera: Sphecidae: Pemphredoninae) // Invertebrate Taxonomy. Vol.2. P.737-747.

Menke A.S. 1997a. A new Ammoplanus Gussakovskij [sic] (Hymenoptera: Sphecidae: Pemphredoninae) from San Clemente Island, California // Proceedings of the Entomological Society of Washington. Vol.99. No.1. P.133-135.

Menke A.S. 1997b. Family-group names in Sphecidae (Hymenoptera: Apoidea) // Journal of Hymenoptera Research. Vol.6. No.2. P.243-255.

Menke A.S., F. Fernández C. 1996. Claves ilustradas para las subfamilias, tribus y géneros de esfécidos neotropicales (Apoidea: Sphecidae) // Revista de Biología Tropical. Vol.44 (Supplement). Vol.2. P.1-68

Ohl M., Bennett D.J. 2009. A new genus and species of apoid wasps from Saxonian amber (Hymenoptera: Apoidea: Crabronidae) // Denisia. Vol.86. (Neue Serie 26). P.145-150. 
Michener C.D. 2000. The bees of the world. Baltimore and London: The Johns Hopkins University Press. 913 pp.

Pulawski W.J. 2011. Family group names and classification. (Internet catalog accessed on 1 April 2011): http://research. calacademy.org/sites/research.calacademy.org/files/Departments/ent/sphecidae/Family group names and classification.pdf

Rasnitsyn A.P., Jarzembowski E.A., Ross A.J. 1998. Wasps (Insecta: Vespida $=$ Hymenoptera) from the Purbeck and Wealdon (Lower Cretaceous) of southern England and their biostratigraphical and paleoenvironmental significance // Cretaceous Research. Vol.19. P.329-391.

Smith N.J. 1983. New North American Pulverro Pate with a key to the species (Hymenoptera: Sphecidae) // The Pan-Pacific En- tomologist. Vol.59. P.256-266.

Smith N.J. 2009 (2008). A review of Nearctic Ammoplanus Giraud 1869 (Hymenoptera: Crabronidae) // The Pan-Pacific Entomologist. Vol.84. P.301-333.

Smith N.J. 2010. A review of the Nearctic species of Parammoplanus (Pate) with descriptions of new species (Hymenoptera: Crabronidae) // The Pan-Pacific Entomologist. Vol.85. P.107149.

Sorg M. 1986. Grabwespen der Gattung Passaloecus aus fossilen Harzen (Hymenoptera, Sphecoidea, Pemphredoninae). Passaloecus microceras n. sp., baltischer Bernstein, oberes Eozän. Passaloecus munax n. sp., bitterfelder Bernstein, unteres Miozän // Paläontologische Zeitschrift. Bd.60. Hf.3-4. S.277284. 